\title{
STRUCTURAL AND MECHANICAL PROPERTIES OF THE DEVELOPED FRUIT AND BERRY SEMI-FINISHED PRODUCT
}

\author{
Oleksander Cherevko ${ }^{1}$ \\ Cherevko_O@hduht.edu.ua \\ Valerii Mykhaylov ${ }^{l}$ \\ v.mykhailov@hduht.edu.ua \\ Andrii Zahorulko \\ zagorulkoAN@hduht.edu.ua \\ Aleksey Zagorulko ${ }^{1}$ \\ zagorulko@hduht.edu.ua \\ Iryna Gordienko ${ }^{1}$ \\ gordienko_irina@gmail.com \\ ${ }^{1}$ Department of Processes and Equipment Food and Hospitality-Restaurant Industry named after \\ M. Belaev \\ Kharkiv State University of Food Technology and Trade \\ 333 Klochkivska str., Kharkiv, Ukraine, 61051
}

\begin{abstract}
One of progress directions of the modern food industry is the development and introduction of innovative technologies and assortment of functional food products, allowing to decrease risks of disease progression and favoring the population health.

Such products include multicomponent fruit and berry pastes and dried powder fractions. They are natural vitamin carriers, may be used as a supplement or a base for creating a wide spectrum of food products with healthy properties.

A production way for fruit and berry semi-finished product using non-traditional raw materials has been created. For creating paste or dried faction, raw materials with a high content of pectins for better structuring and with correspondent healing-prophylactic properties were selected. Apple was taken as a base of the paste with adding non-traditional raw materials ziziphus and black aronia. The way differs by the process of dehydration by concentrating up to $44 \ldots 46 \%$ of dry substances in a rotor evaporator, then, if necessary, additional drying in a thermoradiative one-drum rolling dryer up to $5 . .8 \%$ of dry substances.

Structural-mechanical parameters of experimental samples of the paste after concentrating up to $45 \%$ content of dry substances have been determined. An effective viscosity increase for all three experimental samples as $33 . . .59 \%$ comparing with apple paste has been established. It is explained by higher content of pectin substances in ziziphus. The most effective viscosity index is $584 \mathrm{~Pa} \cdot \mathrm{s}$ belongs to a sample with the components content: apple $-50 \%$, ziziphus $-45 \%$, black aronia $-5 \%$.

The developed semi-product may be used as a vitamin supplement, filler or thickener at producing functional food products in confectionary, milk, bakery industry and also for preparing dishes and drinks at restaurant economies and under home conditions.
\end{abstract}

Keywords: fruit and berry semi-finished product, paste, powder-like fraction, effective viscosity, concentrating, drying.

DOI: $10.21303 / 2504-5695.2021 .001630$

\section{Introduction}

One of progress directions of the modern food industry is development and introduction of innovative technologies and assortment of functional food products, allowing to decrease risks of disease progression and favoring the population health $[1,2]$. Such products include multicomponent fruit and berry pastes and dried powder fractions. They are natural vitamin carriers, may be 
used as a supplement or a base for creating a wide spectrum of food products with healthy properties. Paste-like and powder-like semi-products are widely used at producing confectionary, milk, meat, bakery, macaroni and other products, not only for enriching them with functional ingredients, but also for giving them new technological properties.

Modern studies as to improving technologies of getting semi-finished products of fruits and berries, destined for using as components of food products, are vary urgent [3]. Creation of high-quality fruit and berry semi-products is based on usage of high technologies and observance of parameters of blanching, concentrating, drying with own regulations for each raw material type. Such approach to raw materials processing obliges producers to control preparation, thermal processing and storage conditions of raw materials more carefully [4]. A task to preserve a natural color, taste and smell of raw materials is put.

That is why it is very urgent to develop a recipe composition of the semi-product and technology of its production for providing maximally full preservation of the vitamin composition, color, aromatic components and other thermolabile substances. It conditions the use of technological processes of natural raw materials dehydration under conditions of searching new ways for improving methods and apparatus maintenance for their realization [5].

An important stage of getting paste-like semi-products is concentrating of prepared fruit and berry puree by the technologically necessary way to the consistence with dry substances content $18 \ldots 45 \%$ [6]. Concentrating in most existing evaporating apparatuses lasts from 90 to $360 \mathrm{~min}$, at that, essential losses of physiologically functional ingredients take place. That is why it is necessary for food industry enterprises to improve and to introduce technological equipment, which use provides paste-like semi-products of quality, raised at the expanse of using low-temperature regimes [7].

At processing vegetable raw materials in paste-like semi-products, it is necessary to take into account their structural-mechanical parameters for revealing a product's behavior in the technological equipment and at forming functional product recipes $[8,9]$.

The aim of the work is to develop a method of production and recipe of high-quality fruit and berry pastes and dried fractions and to study structural-mechanical properties of pastes for further experimental and calculating researches of dehydrating processes in the developed equipment.

\section{Research materials and methods}

Ripen fruit and vegetable raw materials, planted within the Kharkiv region, were used for the studies: apple (Antonivka), ziziphus (Ta-yan-tsao) and black aronia (Chornooka), Fig. 1 [10]. The recipe ratio of blended fruit and berry samples is presented in Table $\mathbf{1}$.

Table 1

Components ratio in samples at blending

\begin{tabular}{cccc}
\hline Component composition & $\mathbf{1}$ & $\mathbf{2}$ & $\mathbf{3}$ \\
\hline Apple & 70 & 60 & 50 \\
Ziziphus & 25 & 35 & 45 \\
Black aronia & 5 & 5 & 5
\end{tabular}

The use of different types of raw materials allows to get original recipes with certain structural-mechanical and organoleptic parameters and increased content of physiologically functional ingredients. For revealing the rational recipe of blended compositions, experimental samples were prepared with the total mass of $100 \mathrm{~g}$, with three iterations of experiments. The analysis of changes of structural-mechanical parameters of the blended compositions was conducted at comparing with a control sample - apple paste (Table 1). The studies of structural-mechanical parameters of model samples of the fruit and berry pastes were conducted at a rotation viscosimeter "Rheotest 2 " in a cylindric measuring device by Kuet. According to the recipe ratio (Table 1), apple paste was used as a control. 


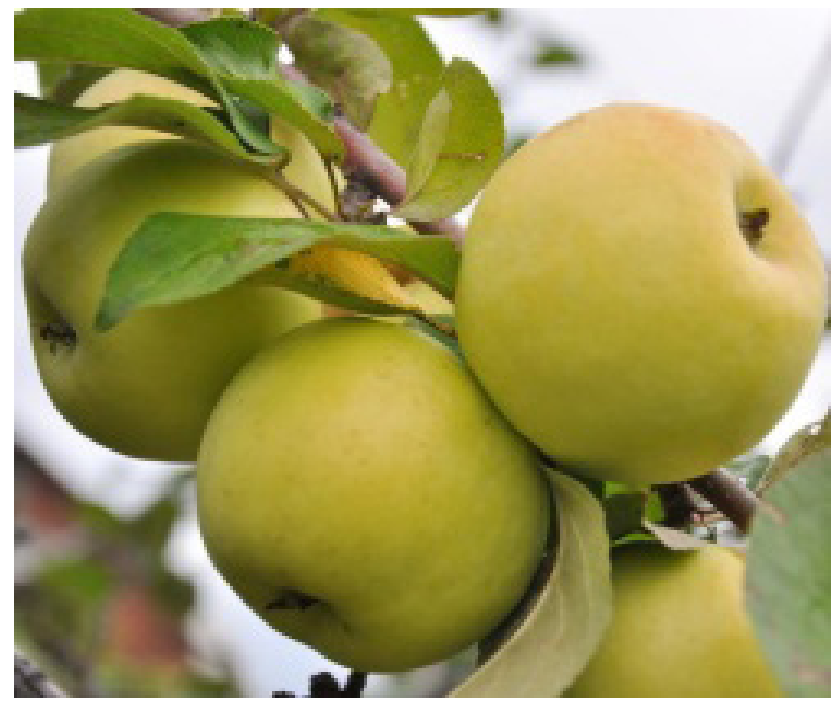

$a$

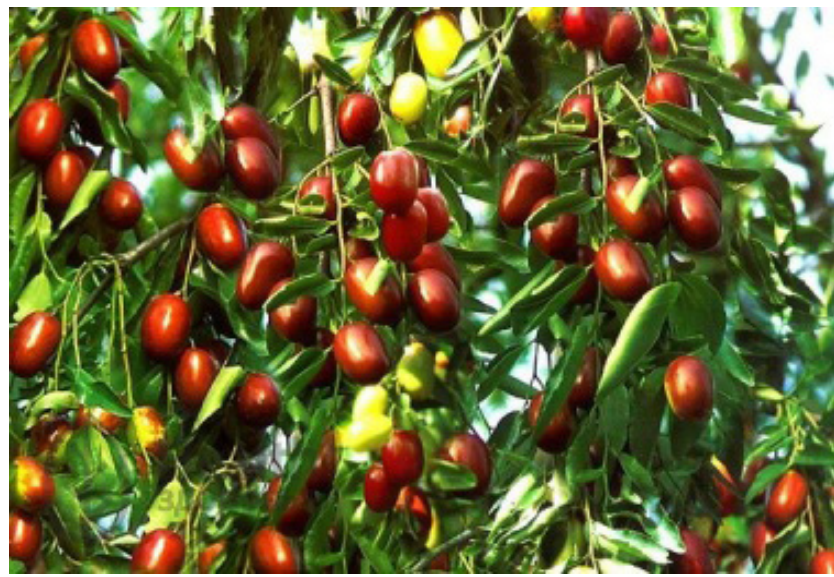

$b$

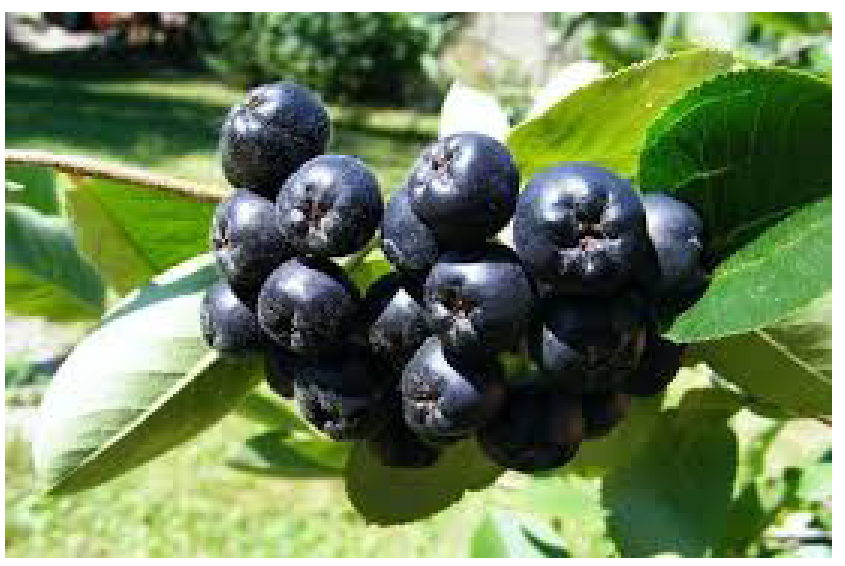

Fig. 1. Outlook of experimental samples: $a$-apple; $b$ - ziziphus; $c$ - black aronia

\section{Research results and their discussion}

The production technology for fruit and berry paste using non-traditional raw materials has been developed. For creating the paste, raw materials with a high content of pectins for better 
structuring and with correspondent healing-prophylactic properties were selected. Apple was taken as a base of the paste with adding non-traditional raw materials - ziziphus and black aronia.

Ziziphus is very helpful for health at eating. Its consumption favors removal of toxic substances and cholesterol from the human organism. It contains (\%): sugar $-24 \ldots .33$; pectin $-2 \ldots 6$; vitamin $\mathrm{C}-240 \ldots 1300$ (mg \%) and other healthy substances. One more important property of this exotic fruit is a perfect ability to clean blood vessels and also to strengthen their walls. Healthy properties of ziziphus are perfectly preserved even after the process of thermal culinary processing. Black aronia has the black coloration of fruits (underlined by its name): they contain many anthocyans, giving obtained mixings a saturated violet color. Aronia fruits are rich in vitamin $\mathrm{C}$, pectin, sugars, carotene, tanning substances and organic acids.

The production process of fruit and berry semi-finished products (Fig. 2) was realized by the new way, differed by the component content of the offered raw materials (Table 1) and low-temperature processing regimes at heat removal by an innovative electric membranous heater [11].

The developed method includes the following: fruits of ziziphus and black aronia are washed, inspected, separately blanched by steam or water during 3..6 min in a specially developed multifunctional apparatus. After that they are rubbed on a rubbing machine with orifices diameter $0.5 \ldots 0.7 \mathrm{~mm}$. Pits, skin and flesh residues, obtained by rubbing, are boiled during $5 \ldots 10 \mathrm{~min}$, at that the ratio between the skin and pits mass with flesh and the water mass is 1:0.5...1:0.7. The mass, obtained in such a way, is rubbed. Apple puree is prepared by the actual technology for fruit and vegetable purees.

At the next stage the mass of ziziphus and black aronia is blended, the rubbed mass of skin and pits broth of these fruits is carefully mixed with apple puree. The blended puree is heated to temperature $48 \ldots .52{ }^{\circ} \mathrm{C}$ and put for membranous concentrating under vacuum in the improved rotor evaporator at temperature $58 \ldots 68^{\circ} \mathrm{C}$ to dry substances content $44 \ldots 46 \%$ during $45 \ldots 85 \mathrm{~s}$. The obtained boiled paste is packed at temperature $65 . .70{ }^{\circ} \mathrm{C}$, corked, pasteurized and marked.

The technology provides getting a powder-like structure of the semi-finished product. For that, the obtained paste is put for drying in the improved thermoradiative one-drum rolling dryer, where it is dried to humidity $5 \ldots 8 \%$ at temperature $64 \ldots 65{ }^{\circ} \mathrm{C}$ during $50 \ldots 60 \mathrm{~min}$.

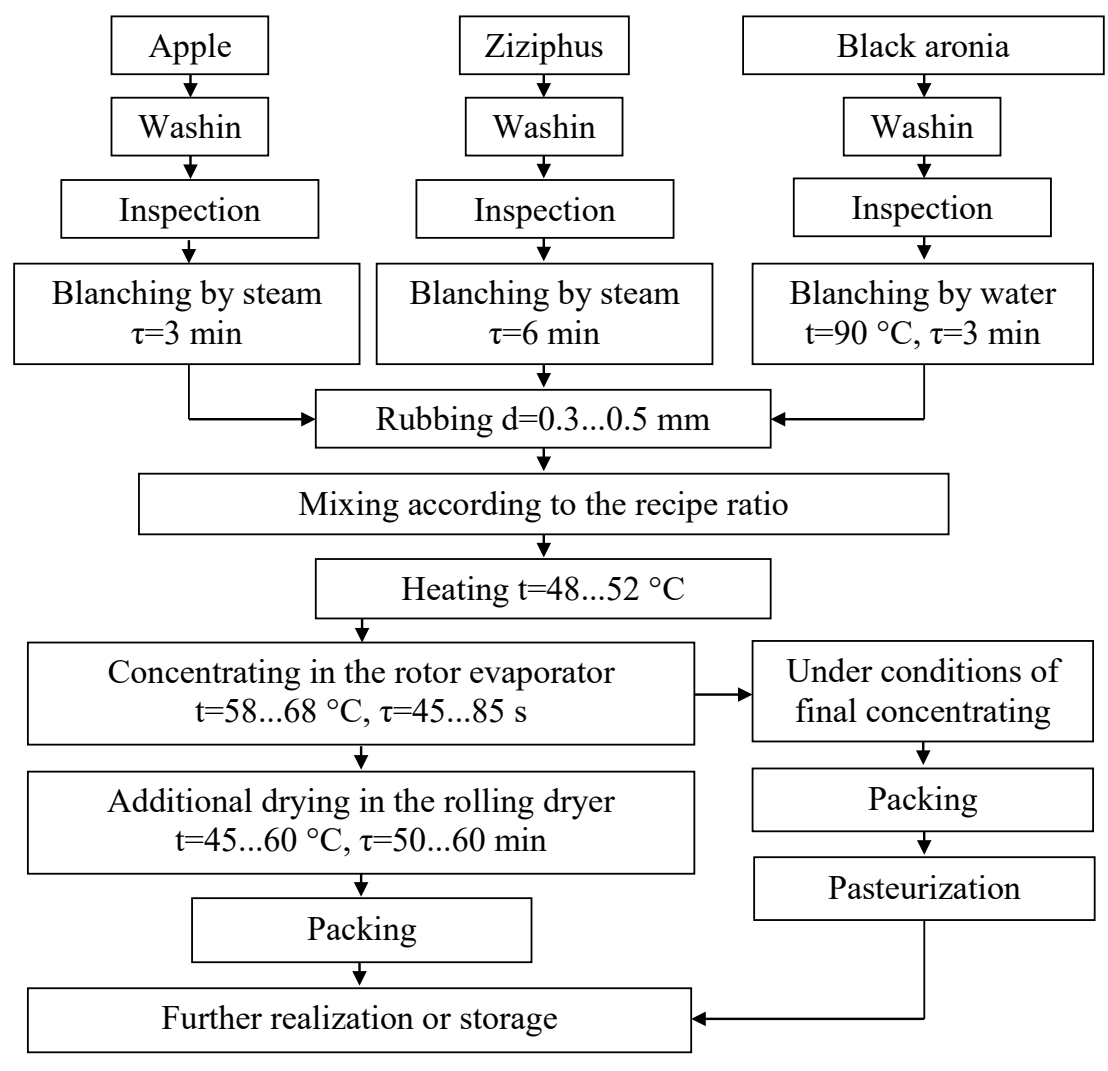

Fig. 2. Production method of fruit and berry paste- and powder-like semi-finished products 
For establishing the creation process of the mechanism of structure deformation and destruction and also for calculating pipelines and working units of apparatuses, changes of structural-mechanical parameters of paste-like composition were studied.

The obtained dependencies of the effective viscosity on the shear speed of the samples (Table 1) according to the developed method, are presented on Fig. 3. The initial value of effective viscosity for non-destructed composition samples of the pastes are (Pa·s): $1-397 ; 2-536 ; 3-584$ and control - 182 respectively. Such behavior of curves corresponds to the structure of solid-like imperfectly plastic bodies.

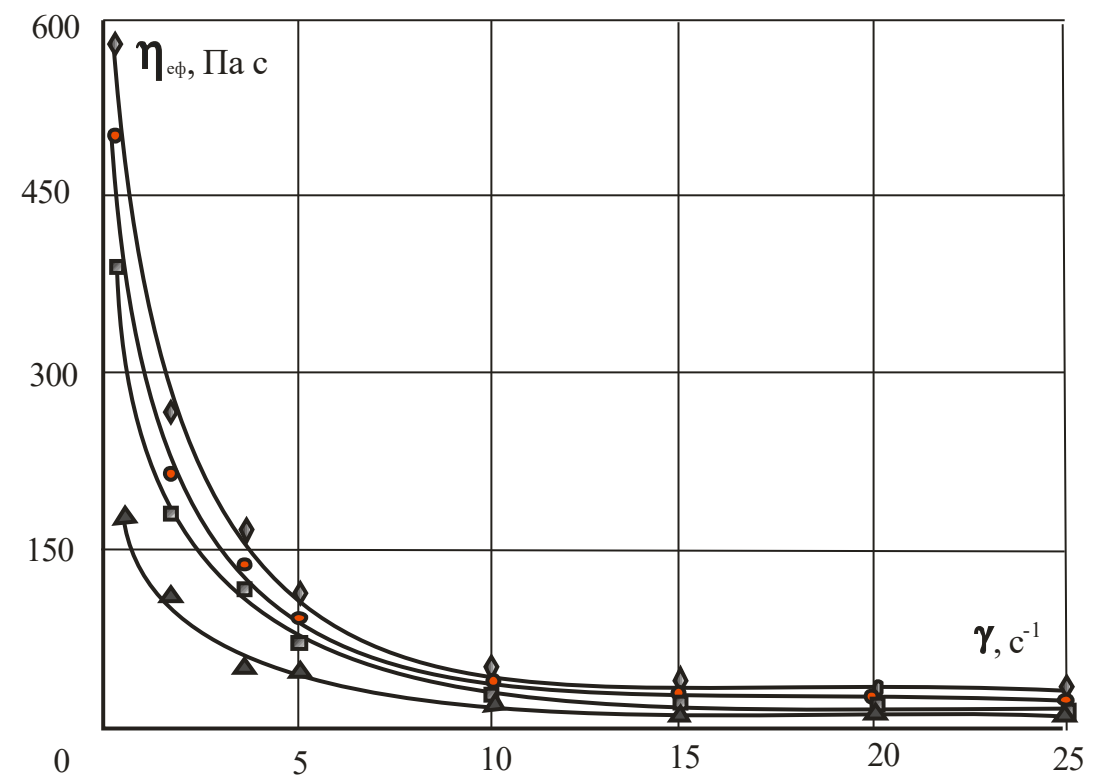

Fig. 3. Complete rheological curve of the pastes at $t=20^{\circ} \mathrm{C}$, DS $-45 \%$ : $\boldsymbol{\Delta}$ - apple paste; composition 1 ; $\bullet$ - composition 2 ; - composition 3

At the analysis it has been established, that introduction of more percent content of ziziphus results in the growing effective viscosity due to the increased pectin content in its composition that positively influences strengthening of the obtained product structure.

\section{Conclusions}

The production method for fruit and berry paste using non-traditional raw materials has been developed. For creating paste or dry substance, raw materials with a high content of pectins for better structuring and with correspondent healing-prophylactic properties were selected. Apple was taken as a base of the paste with adding non-traditional raw materials - ziziphus and black aronia. The way is characterized by the process of dehydration by concentrating up to $44 \ldots 46 \%$ of dry substances in the rotor evaporator, then, if necessary, additional drying in a thermoradiative one-drum rolling dryer up to $5 . .8 \%$ of dry substances.

Structural-mechanical parameters of experimental samples of the paste after concentrating up to $45 \%$ content of dry substances have been determined. The effective viscosity increase for all three experimental samples as $33 \ldots . .59 \%$ comparing with apple paste has been established. It is explained by higher content of pectin substances in ziziphus. The most effective viscosity index as $584 \mathrm{~Pa} \cdot \mathrm{s}$ belongs to sample 3 with the components content: apple $-50 \%$, ziziphus $-45 \%$, black aronia $-5 \%$.

The developed semi-product may be used as a vitamin supplement, filler or thickener at producing functional food products in confectionary, milk, bakery industry and also for preparing dishes and drinks at restaurant economies and under home conditions. The developed production method of semi-products allows to widen the assortment of functional products with the improved quality. 


\section{References}

[1] Funktsional'naya harakteristika pererabotannyh plodov i ovoshchey. Available at: https://znaytovar.ru/new708.html

[2] Vyrobnytstvo orhanichnoi silhospproduktsiyi ta syrovyny. Ahrobiznes sohodni. Available at: http://agro-business.com.ua/ agro/u-pravovomu-poli/item/1858-vyrobnytstvo-orhanichnoi-silhospproduktsii-ta-syrovyny.html

[3] Pylypenko, O. (2017). Development of Ukrainian food industry. Scientific Works of NUFT, 23 (3), 15-25.

[4] Asortyment plodovo-yahidnykh konserviv. Available at: https://foodtechnology.pro/tehnologiya-pererobki-plodiv-ta-vochiv/ asortiment/asortiment-plodovo-yagidnih-konserviv

[5] Pavlyuk, R. Yu., Cherevko, A. I., Ukrainets, A. I. et. al. (2003). Novye fitodobavki i ih ispol'zovanie v produktah pitaniya. Kharkiv; Kyiv: Khark. gos. un-t pitaniya i torgovli; Kyivsk. nats. un-t pishch. tehnologiy, 287.

[6] Marco, S. C., Adrien, S., Isabelle, M., Manuel, V. O., Dominique, P. (2019). Flash Vacuum-Expansion Process: Effect on the Sensory, Color and Texture Attributes of Avocado (Persea americana) Puree. Plant foods for human nutrition (Dordrecht, Netherlands), 74 (3), 370-375. doi: https://doi.org/10.1007/s11130-019-00749-3

[7] Pogarskaya, V. V., Cherevko, A. I., Pavlyuk, R. Yu. et. al. (2007). Novye tehnologii funktsional'nyh ozdrovitel'nyh produktov. Kharkiv, 262.

[8] Huang, L., Bai, L., Zhang, X., Gong, S. (2019). Re-understanding the antecedents of functional foods purchase: Mediating effect of purchase attitude and moderating effect of food neophobia. Food Quality and Preference, 73, $266-275$. doi: http://doi.org/10.1016/j.foodqual.2018.11.001

[9] Borchani, M., Masmoudi, M., Amira, A. B., Abbès, F., Yaich, H., Besbes, S. et. al. (2019). Effect of enzymatic treatment and concentration method on chemical, rheological, microstructure and thermal properties of prickly pear syrup. LWT-Food science and technology, 113, 108314. doi: https://doi.org/10.1016/j.lwt.2019.108314

[10] Telezhenko, L. N., Bezusov, A. T. (2004). Biologicheski aktivnye veshchestva fruktov i ovoshchey: sohranenie pri pererabotke. Odessa: Optimum, 268.

[11] Cherevko, O. I., Mykhailov, V. M., Zahorulko, O. Ye., Zahorulko, A. M., Maiak, O. A., Samokhvalova, O. V. et. al. (2020). Innovatsiyni tekhnolohiyi ozdorovchykh kharchovykh produktiv na osnovi roslynnoi syrovyny ta obladnannia dlia yikh realizatsiyi. Ch. 1. Rozrobka tekhnolohiy ta obladnannia dlia vyrobnytstva napivfabrykativ z roslynnoi syrovyny. Kharkiv: Vydavnytstvo Ivanchenka I.S., 131. 